\title{
CYP2D6 polymorphisms and the therapeutic outcome with Tamoxifen therapy in breast cancer patients from Kosovo
}

\author{
Selvete Shuleta-Qehaja ${ }^{1 *}$, Aleksandra Kapedanovska Nestorovska ${ }^{2}$, \\ Zorica Naumovska ${ }^{2}$, Petar Stefanovski ${ }^{3}$, Aleksandar J Dimovski ${ }^{2}$, Zoran Sterjev ${ }^{2}$, \\ Ljubica Shuturkova $^{2}$ \\ ${ }^{1}$ Kosovo Medicines Agency, University Clinical Center n.n., Pristina, Kosovo \\ ${ }^{2}$ Ss Cyril and Methodius University, Faculty of Pharmacy, Majka Tereza 47, Skopje, \\ Republic of Macedonia \\ ${ }^{3}$ Clinical Hospital Dr. Trifun Panovski, Department of Oncology, ASNOM n.n., Bitola, \\ Republic of Macedonia
}

Received: November 2018; Accepted: January 2019

\begin{abstract}
Tamoxifen is a selective estrogen receptor modulator (SERM) used for the prevention of breast cancer and for the treatment of metastatic and early stage receptor positive breast cancer. It has been shown than tamoxifen is metabolized by the cytochrome P450 2D6 (CYP2D6) enzymes, especially with the CYP26 isoform. The aim of this study was to examine the prevalence of CYP2D6*4, CYP2D6*9 and CYP2D6*10 variants in patients with breast cancer in Kosovo as well as the association between CYP2D6 polymorphisms and the therapeutic outcome in tamoxifen treated patients. The study included 111 patients who were at the age of 25 to 70 years $(45.75 \pm 9.50)$. The overall variant allele frequency of CYP2D6*4 was 0.16 . The genotypic frequencies of the CYP2D6*4 polymorphism in all patients were 0.02 for $* 4 / * 4,0.28$ for $* 1 / * 4$ and 0.70 for the $* 1 / * 1$ genotype. The overall CYP2D6*10 variant allele frequency was 0.30 and the frequency of $* 10 / * 10, * 1 / * 10$ and $* 1 / * 1$ genotypes was $0.11,0.37$ and 0.52 , respectively. In our study, a population of the CYP2D6*9 variant allele was not detected. In addition, we did not find any correlation between the evaluated genotypes for CYP2D6 polymorphisms and the therapeutic outcome with tamoxifen therapy. Although our study is a rather small- scale compared to large multicentre studies, we believe that it will contribute to determining the impact of CYP2D6 polymorphisms on the success of tamoxifen therapy in patients with a diagnosed breast cancer. Our results are pointing to the direction of the growing number of claims that there is still no strong evidence of any therapeutic connection between the polymorphisms examined and the outcome of the therapy.
\end{abstract}

Keywords: Tamoxifen, breast cancer, CY2D6*4, CYP2D6*9, CYP2D6*10

\section{Introduction}

In women, breast cancer is the most common cancer diagnosed in both more and less developed regions, with more cases registered in less developed (883,000 cases) than more developed regions (794,000 cases). Overall, there were nearly 1.7 million new cases diagnosed in 2012 (Ferlay et al., 2014). Despite the fact that there are numerous uncertainties surrounding the etiology of breast

\footnotetext{
*sshuleta@yahoo.com
} 
cancer, intensive epidemiological, clinical, and genetic studies have identified a number of biological and social traits as risk factors associated with breast cancer. The first and foremost among them is the evidence of BRCA1 and BRCA2 susceptibility genes, familial history of breast cancer, age, higher socioeconomic status, ionizing radiation, life span length, alcohol consumption, and a variety of hormone and metabolic factors. Among the hormonal influences, a relevant etiological function has been ascribed to elevated levels of estrogens, their active metabolites, and androgens (Muti et al, 2006).

The diagnosed breast cancer cases can be classified as follows: hereditary (5-10\%), i.e. correlated with a mutated phenotype of a specific gene segregation with a Mendelian inheritance pattern in families; familial (15$20 \%$ ), i.e. one or more first- and/or second-degree relatives of the proband affected by breast cancer, in the absence of Mendelian inheritance and/or of an identified cancer-causing germline mutation of a specific gene; or sporadic (70-80\%), namely the lack of breast cancer among a patient's first- and/or second-degree relatives (Marchetti et al., 2004).

The pharmacogenetics of cancer therapy has been of great importance. Many of the anticancer drugs are prodrugs and are metabolized to an active form mediated by enzymes. The goal of personalized medicine for breast cancer will require the incorporation of the genetic background of an individual as well as their tumor characteristics into management decision algorithms (Trainer et al., 2004).

Tamoxifen, a selective ER modulator, is used as a first-line endocrine agent for the treatment of breast cancer. Tamoxifen is beneficial in pre- and postmenopausal women whose tumors are ER positive. The pharmacological activity of tamoxifen is dependent upon its conversion by the hepatic drug-metabolizing enzyme cytochrome P450 2D6 (CYP2D6) to its abundant metabolite, endoxifen. The CYP2D6 enzyme, coded by the corresponding gene, plays a major role in the biotransformation of tamoxifen to endoxifen. Therefore, the use of CYP2D6 genotype information to guide tamoxifen therapy represents an early example of a pharmacogenetic tool for optimizing the anticancer efficacy (Hoskins et al., 2009). CYP2D6 has a highly polymorphic expression, and more than 100 variant alleles have been described so far. This enzyme is involved in the metabolism of $20-25 \%$ of clinically used drugs and exhibits a clinically relevant gene polymorphism that modifies the pharmacokinetics of nearly $10 \%$ of drugs. Among major variant alleles in Caucasians, those caused by single-nucleotide polymorphisms (SNPs), namely CYP2D6*4 and CYP2D6*10, account for $15-20 \%$ of the alleles. In addition, variant alleles resulting from CYP2D rearrangements, characterized by CYP2D6 gene deletion (CYP2D6*5) or duplication/multiplication (CYP2D6*xn), are present with allele frequencies of $2-7 \%$ and $1-10 \%$, respectively in Caucasian individuals (Ledesma \&
Agundez., 2005; Pinto \& Dolan., 2011). There have been numerous studies and the effect of CYP2D6 polymorphism on tamoxifen clinical outcome is still under on-going analyses since there are contradictory results among them. The aim of our study was to determine whether or not testing for cytochrome P4502D6 (CYP2D6) polymorphisms in women with early hormone receptor positive breast cancer leads to the improvement of outcomes and is useful for health decision-making.

\section{Material and methods}

The total of 111 patients with breast cancer from Kosovo were subject to our study analyses. All patients had been on tamoxifen treatment (20 mg/day) (TAM patients) for at least 4 weeks as adjuvant therapy. Patients on co-prescribed CYP inhibitors were excluded from this study. The stage of disease, hormonal and HER-2/neu receptor status of the patients, menopausal status and the type of therapy are displayed in Table 1.

In order to evaluate the association between CYP2D6 polymorphisms and therapeutic outcome we divided the patients into two groups: patients with the disease and the second group consisted of patients with a stable condition of the illness. Genomic DNA was extracted from the whole blood, using a QIAGEN DNA extraction kit and the procedure recommended by the manufacturer (QIAGEN AS, Oslo, Norway). The presence of the CYP2D6 polymorphisms - CYP2D6*4 (rs3892097), CYP2D6*9 (rs5030656) and CYP2D6*10 (rs 1065852) were analyzed with the allelic discrimination TaqMan assay (MxPro 3005P, Strategene, La Jolla, CA) according to the manufacturer's instructions (Applied Biosystems, Foster City, CA). The study was approved by the Ethics Committee of the University Clinical Center of Pristina.

Observed and expected allele and genotype frequencies were evaluated for Hardy-Weinberg equilibrium using the Chi-squared test. The Fisher exact test was used to evaluate the association between CYP2D6 variant alleles and treatment outcome. A P-value $<0.05$ was considered statistically significant.

\section{Results}

The study, as stated above, included 111 patients who were at the age of 25 to 70 years $(45.75 \pm 9.50)$. Regarding the results of our study, we did not find any connection between the patients' age and their different disease stages. The mean age of patients with a diagnosis stage IA+IB was $44.75 \pm 7.97(\mathrm{CL}(95 \%)=6.67)$, with stage II of the disease was $46.36 \pm 10.10$ (CL $(95 \%)=$ $2.59)$ and with stage III was $44.36 \pm 8.56$ (CL (95\%) $=$ 3.03). Most of the patients, $73.87 \%$, were on the therapeutic protocol Cyclophosphamide, doxorubicin, 5- 
Table 1. Characteristics of the patients

\begin{tabular}{|c|c|}
\hline Characteristics & TOTAL N=111 \\
\hline \multicolumn{2}{|l|}{ Age } \\
\hline Age at diagnosis ALL (mean) & 45.75 [SD 9.50804; CL 95\% 1.84908] \\
\hline Age at diagnosis-IA+IB (mean) & 44.75 [SD 7.97765; CL 95\% 6.66948] \\
\hline Age at diagnosis-II stage (mean) & 46.36 SD 10.10616; CL 95\% 2.58831] \\
\hline Age at diagnosis- III stage (mean) & 44.36; [SD 8.56161; CL 95\% 3.03581] \\
\hline Stage of disease & $\%$ \\
\hline IA & 4.50 \\
\hline IB & 2.70 \\
\hline IIA & 27.93 \\
\hline IIB & 27.03 \\
\hline IIIA & 9.91 \\
\hline IIIB & 5.41 \\
\hline IIIC & 14.41 \\
\hline Unknown & 8.11 \\
\hline \multicolumn{2}{|l|}{ Receptor status } \\
\hline \multicolumn{2}{|l|}{ ER } \\
\hline neg & 0.90 \\
\hline pos & 98.20 \\
\hline unknown & 0.90 \\
\hline \multicolumn{2}{|l|}{$\mathrm{PgR}$} \\
\hline neg & 3.60 \\
\hline pos $(+$ low $)$ & 95.50 \\
\hline unknown & 0.90 \\
\hline
\end{tabular}

HER-2/neu

Menopausal

$\begin{array}{rcc}\text { neg } & 98 & 88.29 \\ \text { pos } & 10 & 9.01 \\ \text { unknown } & 3 & 2.70\end{array}$

$\begin{array}{rcc}\text { yes } & 62 & 55.86 \\ \text { no } & 42 & 37.84 \\ \text { unknown } & 7 & 6.31\end{array}$

Type of adjuvant chemotherapy

cyclophosphamide, doxorubicin, $\begin{array}{lll}\text { docetaxel } & 12 & 10.81\end{array}$

cyclophosphamide, doxorubicin, 5-FU

$82 \quad 73.87$

cyclophosphamide, doxorubicin

$1 \quad 0.90$

cyclophosphamide, docetaxel 
Adjuvant radiation therapy

$\begin{array}{rcc}\text { yes } & 42 & 37.84 \\ \text { no } & 62 & 55.86 \\ \text { unknown } & 7 & 6.31\end{array}$

Type of hormonal therapy

$\begin{array}{lll}\text { Tamoxifen } & 111 & 100.00\end{array}$

Disease progression

$\begin{array}{rcc}\text { yes } & 18 & 16.22 \\ \text { no } & 85 & 76.58 \\ \text { unknown } & 8 & 7.21\end{array}$

Abbreviations: $N$-number; SD-standard deviation; $C L$-Confidence Level; ER -estrogen receptor,

PgR-progesterone receptor, HER-2/neu -Human epidermal growth factor 2, 5-FU - Fluorouracil

FU. The mean age in this group of patients was $45.83 \pm$ $9.67(\mathrm{CL}(95 \%)=2.12)$. From the other patients, $10.81 \%$ were included on the therapeutic protocol with cyclophosphamide, doxorubicin, docetaxel, and $7.21 \%$ on the therapeutic protocol with Doxorubicin and 5-FU.

All 111 patients were genotyped for CYP2D6 polymorphisms. The distribution of CYP2D6*4 and CYP2D6*10 variant was in accordance with the HardyWeinberg expectations. The overall variant allele frequency of CYP2D6*4 was 0.16 . The genotypic frequencies of the CYP2D $6 * 4$ polymorphism in all patients were 0.02 for $* 4 / * 4,0.28$ for $* 1 / * 4$ and 0.70 for the $* 1 / * 1$ genotype. The overall CYP2D6*10 variant allele frequency was 0.30 and the frequency of $* 10 / * 10$, $* 1 / * 10$ and $* 1 / * 1$ genotypes were $0.11,0.37$ and 0.52 , respectively. In our study population, the CYP2D6*9 variant allele was not detected.

Twenty-eight of all patients $(25 \%)$ were homozygotes for the normal alleles for both polymorphisms (CC for CYP2D6*4 and $\mathrm{CC}$ for CYP2D6*10). We did not identified patient who were homozygotes for variant alleles for both polymorphisms (CC for CYP2D6*4 and CC for CYP2D6*10). The correlation analysis between CYP2D6 status and the therapeutic outcome was performed only in subgroup of patients with positive genotyping reaction and known disease status (Disease progression or Survived). The allele and genotype frequencies in the patient population stratified according to the treatment outcome (Disease progression vs. Stable) for $C Y P 2 D 6^{*} 4, C Y P 2 D 6^{*} 9$ and CYP2D6*10 polymorphisms are presented in Table 2. No significant differences in the allelic frequencies and genotype distribution between the two patient groups were observed ( $p$ Fisher Exact test > 0.05).

\section{Discussion}

The pharmacogenetics of cancer therapy is of significant priority. Many of the anticancer drugs are pro- drugs and are metabolized to an active form mediated by enzymes. The catalytic efficiency of enzymes involved in the catalysis of pro-drugs is variable in individuals. Cytochrome P450 2D6 (CYP2D6) has a high relevance in drug metabolism. CYP2D6 is involved in the metabolism of $20-25 \%$ of clinically used drugs and exhibits a clinically relevant gene polymorphism that modifies the pharmacokinetics of nearly $10 \%$ of the drugs used (Pinto \& Dolan, 2011).

The aim of this population-based case-control study was to define the prevalence of the CYP2D6*4, CYP2D6*9 and CYP2D6*10 variants in patients with breast cancer in the Republic of Kosovo and determine their influence on the therapeutic outcome in tamoxifen treated patients. The frequency of CYP2D6*4 allelic variant in our study population (16\%) was comparable to that found in other Caucasians in the European population (20\%). For the CYP2D6*10, we estimate allelic frequency of $29.8 \%$ which is significantly different from its frequency in other Caucasians 1-2\% (Table 3) (IngelmanSundberg, 2005).

The frequency of CYP2D6*9 variant allele is $<2 \%$ in the European population. In our study group, we did not find any patients with this allele. For that reason, CYP2D6*9 polymorphisms were excluded from further analysis and not evaluated in relation to the tamoxifen treatment outcome.

Regarding the effect of CYP2D6 polymorphism on the tamoxifen clinical outcome, there have been numerous studies and they are still on going. The results among them are contradictory. The heterogeneity of results in the trials has led to confusion and controversy. The conclusions of these studies range from a possible longer disease-free survival interval to a substantially shorter recurrence-free survival time for patients carrying CYP2D6 genotypes conferring diminished tamoxifen metabolism. Tamoxifen-treated patients carrying the CYP2D6 alleles *4, *5,*10,*41 - are associated with an impaired formation of antiestrogenic metabolites and have significantly more recurrences of breast cancer, shorter 
Table 2. Allele and genotype distribution in breast cancer patients

\begin{tabular}{|c|c|c|c|c|c|c|c|c|}
\hline \multirow{2}{*}{ CYP2D6 variant } & \multirow{2}{*}{$\begin{array}{c}\text { Genotype } \\
\text { Allele }\end{array}$} & \multicolumn{4}{|c|}{ Disease progression } & \multicolumn{2}{|c|}{ Stable } & \multirow{2}{*}{$\begin{array}{c}\mathrm{p} \\
\text { (Fisher) }\end{array}$} \\
\hline & & $\mathrm{n}$ & frequencies & expect & $\mathrm{n}$ & frequencies & expected & \\
\hline \multirow{7}{*}{ CYP2D6*4 } & $* 1 / * 1$ & 8 & 0.66 & 0.63 & 51 & 0.71 & 0.72 & \multirow{4}{*}{$\begin{array}{l}0.455 \\
0.153\end{array}$} \\
\hline & $* 1 / * 4$ & 3 & 0.25 & 0.33 & 20 & 0.28 & 0.26 & \\
\hline & $* 4 / * 4$ & 1 & 0.08 & 0.04 & 1 & 0.01 & 0.02 & \\
\hline & total & 12 & 1.00 & 1.00 & 72 & 1.00 & 1.00 & \\
\hline & $* 1$ & 19 & 0.79 & & 122 & 0.85 & & \multirow{3}{*}{0.267} \\
\hline & $* 4$ & 5 & 0.21 & & 22 & 0.15 & & \\
\hline & total & 24 & 1.00 & & 144 & 1.00 & & \\
\hline \multirow{5}{*}{ CYP2D6*9 } & $* 1 / * 1$ & 18 & 1.00 & 1.00 & 72 & 1.00 & 1.00 & \multirow{4}{*}{$\begin{array}{l}1 \\
1 \\
\end{array}$} \\
\hline & $* 1 / * 9$ & 0 & 0.00 & 0.00 & 0 & 0.00 & 0.00 & \\
\hline & $* 9 / * 9$ & 0 & 0.00 & 0.00 & 0 & 0.00 & 0.00 & \\
\hline & total & 18 & 1.00 & 1.00 & 72 & 1.00 & 1.00 & \\
\hline & $* 1$ & 36 & 1.00 & & 144 & 1.00 & & \multirow[b]{3}{*}{1} \\
\hline \multirow{9}{*}{ CYP2D6*10 } & $* 9$ & 0 & 0.00 & & 0 & 0.00 & & \\
\hline & total & 36 & 1.00 & & 144 & 1.00 & & \\
\hline & $* 1 / * 1$ & 10 & 0.63 & 0.56 & 40 & 0.49 & 0.48 & \multirow{4}{*}{$\begin{array}{l}0.270 \\
0.890\end{array}$} \\
\hline & $* 1 / * 10$ & 4 & 0.25 & 0.38 & 32 & 0.40 & 0.43 & \\
\hline & $* 10 / * 10$ & 2 & 0.13 & 0.06 & 9 & 0.11 & 0.10 & \\
\hline & total & 16 & 1.00 & 1.00 & 81 & 1.00 & 1.00 & \\
\hline & $* 1$ & 24 & 0.74 & & 112 & 0.69 & & \multirow{3}{*}{0.507} \\
\hline & $* 10$ & 8 & 0.26 & & 50 & 0.31 & & \\
\hline & total & 32 & 1.00 & & 162 & 1.00 & & \\
\hline
\end{tabular}

relapse-free periods and worse event-free survival rates compared with carriers of CYP2D6 functional alleles (Schroth et al., 2009).

In multicentre studies, including retrospectively and prospectively collected patient data, authors also confirmed the link between a CYP2D6 variation and the clinical outcome in women receiving adjuvant tamoxifen. They found that poor metabolizers (PM) for CYP2D6 enzyme had an almost 2-fold increased risk of developing breast cancer recurrence compared with patients with 2 functional CYP2D6 alleles (extensive metabolizers - EM) (Schroth et al., 2009).

Investigators from the Mayo Clinic and COBRA reported that carriers of a CYP2D6*4 variant allele had a significantly shorter time-to-recurrence and relapse-free survival compared with EM (Higgins \& Stearns, 2010).

In the same year of the initial Mayo/COBRA report, two large retrospective studies reported an inverse association between CYP2D6 genotype and breast cancer (Fox et al., 2016).

An international group of clinicians and scientists representing the Clinical Pharmacogenetics Implementation Consortium (CPIC) have reached a consensus that there is sufficient evidence to use the CYP2D6 genotype to assist with clinical recommendations for women who are being considered for tamoxifen for early stage estrogen receptor positive breast cancer (Goetz et al., 2018). The Dutch Pharmacogenetics Working Group has also made recommendations for a tamoxifen therapy based on the CYP2D6 genotypes. Their recommendation for both poor and intermediate metabolizers, is to consider using aromatase inhibitors for postmenopausal women due to an increased risk of breast cancer relapse with tamoxifen. 
Table 3. Major human polymorphic variant CYP2D6 alleles and their global distribution (Source: Ingelman-Sundberg, 2005)

\begin{tabular}{|c|c|c|c|c|c|c|}
\hline \multirow{2}{*}{$\begin{array}{l}\text { Major variant } \\
\text { alleles }\end{array}$} & \multirow{2}{*}{ Mutation } & \multirow{2}{*}{ Consequence } & \multicolumn{4}{|c|}{ Allele frequencies $(\%)$} \\
\hline & & & Caucasians & Asians & $\begin{array}{c}\text { Black } \\
\text { Africans }\end{array}$ & $\begin{array}{c}\text { Ethiopians } \\
\text { and Saudi } \\
\text { Arabians }\end{array}$ \\
\hline CYP2D6*2xn & $\begin{array}{l}\text { Gene duplication/ } \\
\text { multiduplication }\end{array}$ & $\begin{array}{c}\text { Increased } \\
\text { enzyme activity }\end{array}$ & $1-5$ & $0-2$ & 2 & $10-16$ \\
\hline CYP2D6*4 & Defective splicing & $\begin{array}{l}\text { Inactive } \\
\text { enzyme }\end{array}$ & $12-21$ & 1 & 2 & $1-4$ \\
\hline CYP2D6*5 & Gene deletion & No enzyme & $2-7$ & 6 & 4 & $1-3$ \\
\hline CYP2D6*10 & P34S, S486T & $\begin{array}{l}\text { Unstable } \\
\text { enzyme }\end{array}$ & $1-2$ & 51 & 6 & $3-9$ \\
\hline CYP2D6*17 & $\begin{array}{c}\text { T107I, R296C, } \\
\text { S486T }\end{array}$ & $\begin{array}{l}\text { Altered affinity } \\
\text { for substrates }\end{array}$ & 0 & 0 & $20-35$ & $3-9$ \\
\hline
\end{tabular}

They also recommend that intermediate metabolizers should avoid the concomitant use of CYP2D6 inhibitors. Conversely, The National Comprehensive Cancer Network (NCCN) does not recommend CYP2D6 testing as a tool to determine the optimal adjuvant endocrine strategy (www.ncbi.nlm.nih.gov/books/NBK247013, 2018).

In our study, we did not find any correlation between the evaluated genotypes for CYP2D6 polymorphisms and the therapeutic outcome with tamoxifen therapy. At the beginning, we divided patients into two groups (Disease progression vs. Stable) and each polymorphism was evaluated in relation to the current disease status for the whole group of patients. Afterwards, the patients were divided into the following groups: patients who a were homozygous for both normal alleles of the examined polymorphism, patients who were homozygous for both variant alleles and patients who were heterozygotes for both examined polymorphisms. Although our study is rather a small-case study compared to large multicentre studies, we believe that it will contribute to determining the impact of CYP2D6 polymorphisms on the success of a tamoxifen therapy in patients with diagnosed breast cancer. Our results are pointing to the direction of the growing number of claims that there is still no strong evidence of any therapeutic connection between the polymorphisms examined and the outcome of the therapy.

\section{References}

Dean L. Tamoxifen Therapy and CYP2D6 Genotype. 2014 Oct 7 [Updated 2016 May 3]. In: Pratt V, McLeod H, Rubinstein W, et al., editors. Medical Genetics Summaries [Internet]. Bethesda (MD): National Center for Biotechnology Information (US); 2012. Available at:
https://www.ncbi.nlm.nih.gov/books/NBK247013/. Last accessed: September, 2018.

Ferlay, J., Soerjomataram, I., Ervik, M., Dikshit, R., Eser, S., Mathers, C., Rebelo, M., Parkin, D.M., Forman, D., Bray. F., 2015. Cancer Incidence and Mortality Worldwide: Cancer incidence and mortality worldwide: sources, methods and major patterns in GLOBOCAN 2012. Int. J. Cancer 136 (5), E359-386. Available at: https://doi.org/10.1002/ijc.29210.

Fox, P., Balleine, R.L., Lee, C., Gao, B., Balakrishnar, B., Menzies, A.M., Yeap, S.H., Ali, S.S., Gebski, V., Provan, P., Coulter, S., Liddle, C., Hui, R., Kefford, R., Lynch, J., Wong, M., Wilcken, N., Gurney, H., 2016. Dose escalation of tamoxifen in patients with low endoxifen level: evidence for therapeutic drug monitoring-the TRADE study. Clin. Cancer Res. 22(13), 3164-3171. Available at: https://doi.org/10.1158/1078-0432.CCR-151470 .

Goetz, M.P., Sangkuhl, K., Guchelaar, H.J., Schwab, M., Province, M., Whirl-Carrillo, M., Symmans, W.F., McLeod, H.L., Ratain, M.J., Zembutsu, H., Gaedigk, A., van Schaik, R.H., Ingle, J.N., Caudle, K.E., Klein, T.E., 2018. Clinical Pharmacogenetics Implementation Consortium (CPIC) Guideline for CYP2D6 and Tamoxifen Therapy. Clin. Pharmacol. Ther. 103(5), 770777. Available at: https://doi.org/10.1002/cpt.1007.

Higgins, M.J., Stearns, V., 2010. CYP2D6 Polymorphisms and Tamoxifen Metabolism: Clinical Relevance. Curr. Oncol. Rep. 12(1), 7-15. Available at: https://doi.org/10.1007/s11912-009-0076-5.

Hoskins, J.M., Carey, L.A., McLeod, H.L., 2009. CYP2D6 and tamoxifen: DNA matters in breast cancer. Nat. Rev. Cancer 9(8), 576-586. Available at: https://doi.org/10.1038/nrc2683.

Ingelman-Sundberg, M., 2005. Genetic polymorphisms of cytochrome P450 2D6 (CYP2D6): clinical consequences, evolutionary aspects and functional diversity. Pharmacogenomics J. 5, 6-13. Available at: https://doi.org/10.1038/sj.tpj.6500285. 
Ledesma, M.C., Agundez, J.A.G., 2005. Identification of Subtypes of CYP2D Gene Rearrangements among Carriers of CYP2D6 Gene Deletion and Duplication. Clin.Chem. 51(6), 939-943. Available at: https://doi.org/10.1373/clinchem.2004.046326.

Marchetti, P., Di Rocco, Z.C., Ricevuto, E., Bisegna, R., Cianci, G., Calista, F., Sidoni, T., Porzio, G., Ficorella, C., 2004. Reducing breast cancer incidence in familial breast cancer: overlooking the present panorama. Ann. Oncol. 15(Supp. 1), i27-i34. Available at: https://doi.org/10.1093/annonc/mdh654.

Muti, P., Rogan, E., Cavalieri, E., 2006. Androgens and estrogens in the etiology and prevention of breast cancer. Nutr. Cancer 56(2), 247-52. Available at: https://doi.org/10.1207/s15327914nc5602_17.

Newman, W.G., Hadfield, K.D., Latif, A., Roberts, S.A., Shenton, A., McHague, C., Lalloo, F., Howell, S., Evans, D.G., 2008. Impaired tamoxifen metabolism reduces survival in familial breast cancer patients. Clin. Cancer. Res. 14(18), 5913-5918. Available at: https://doi.org/10.1158/1078-0432.CCR-07-5235.

Pinto, N., Dolan, M.E., 2011. Clinically Relevant Genetic Variations in Drug Metabolizing Enzymes. Curr. Drug.
Metab. 12(5), 487-497. Available at: https://doi.org/10.2174/138920011795495321.

Rideg, O., Háber, A., Botz, L., Szücs, F., Várnai, R., Miseta, A., Kovács, G.L., 2011. Pilot study for the characterization of pharmacogenetically relevant CYP2D6, CYP2C19 and $\mathrm{ABCB} 1$ gene polymorphisms in the Hungarian population. Cell Biochem. Funct. 29, 562-568. Available at: https://doi.org/10.1002/cbf.1788.

Schroth, W., Goetz, MP., Hamann ,U., Fasching, P.A., Schmidt, M., Winter, S., Fritz, P., Simon, W., Suman, V.J., Ames, M.M., Safgren, S.L., Kuffel, M.J., Ulmer, H.U., Boländer, J., Strick, R., Beckmann, M.W., Koelbl. H., Weinshilboum, R.M., Ingle, J.N., Eichelbaum, M., Schwab, M., Brauch, H., 2009. Association between CYP2D6 polymorphisms and outcomes among women with early stage breast cancer treated with tamoxifen. JAMA 302(13), 1429-1436. Available at: https://doi.org/10.1001/jama.2009.1420.

Trainer, A.H., Lewis, C.R., Tucker, K., Meiser, B., Friedlander, M., Ward, R.L., 2010. The role of BRCA mutation testing in determining breast cancer therapy. Nat. Rev. Clin. Oncol. 7(12), 708-717. Available at: https://doi.org/10.1038/nrclinonc.2010.175.

\title{
CYP2D6 полиморфизам и исход од терапија со Тамоксифен кај пациентки со канцер на дојка од Косово
}

\section{Селвете Шулета Ќехаја ${ }^{1 *}$, Александра Капедановска Несторовска ${ }^{2}$, Зорица Наумовска ${ }^{2}$, Петар Стефановски ${ }^{3}$, Александар Ј Димовски ${ }^{2}$, Зоран Стерјев ${ }^{2}$, Љубица Шутуркова ${ }^{2}$}

\author{
${ }^{1}$ Агенција за лекови Косово, Универзитетски Клинички Центар Косово б.б, \\ Приштина, Косово \\ ${ }^{2}$ Универзитет ,Св Кирил и Методиј”, Фармацевтски факултет, Мајка Тереза 47, \\ Скопје, Р. Македонија \\ ${ }^{3}$ Клиничка болница Др. Трифун Пановски, Оддел за онкологија, ул. АСНОМ б.б, \\ Битола, Р. Македонија
}

\begin{abstract}
Клучни зборови: тамоксифен, карцином на дојка, CY2D6*4, CYP2D6*9, CYP2D6*10
\end{abstract}
Тамоксифенот е селективен естроген рецепторен модулатор (SERM) кој се применува за превенција на рак на дојка и за третман на метастатски рак на дојка. Метаболизмот на тамоксифен се одвива преку цитохром Р450 (CYP) ензимите (CYP2D6). Целта на оваа студија беше да се испита преваленцата на CYP2D6*4, CYP2D6*9 и CYP2D6*10 полиморфизмите во CYP2D6 генот кој ја кодира синтезата на истоимениот ензим кај пациенти со карцином на дојка во Косово и да се утврди можната поврзаност помеѓу овие генетски варијанти и терапевтскиот исход кај пациенти третирани со тамоксифен. Во студијата беа вклучени 111 пациенти на возраст од 25 до 70 години $(45,75 \pm 9,50)$. Утврдената алелна фреквенција за CYP2D6*4 полиморфизмот изнесуваше 0,16. Дистрибуцијата на $* 4 / 44, * 1 / * 4$ и *1/*1 генотповите изнесуваше 0,$02 ; 0,28$ и 0,70 , соодветно. 
Вкупната алелна фреквенција на CYP2D6 * 10 беше 0,30 , а фреквенцијата за $* 10 / * 10, * 1 / * 10$ и $* 1 / * 1$ генотипови беше 0,$11 ; 0,37$ и 0,52 , соодветно. Во испитуваната популација CYP2D6 * 9 алелна варијанта не беше идентификувана. Не е идентификувана корелација помеѓу евалуираните генотипови за полиморфизмите на CYP2D6 и терапевтскиот исход со терапија со тамоксифен. Иако нашата студија е помала во обем споредбено со големите мултицентристички студии, веруваме дека ќе придонесе за одредување на влијанието на CYP2D6 полиморфизмите врз успехот на терапијата со тамоксифен кај пациенти со дијагностициран рак на дојка. Нашите резултати се во насока на се́ поголемиот број на тврдења дека сеуште не постојат силни докази за каква било терапевтска врска помеѓу CYP2D6 полиморфизмите и исходот од терапијата со тамоксифен. 